\title{
FAST DISSOLVING TABLETS OF PIMOZIDE: DESIGN, OPTIMIZATION AND IN VITRO CHARACTERIZATION
}

\author{
Raja Rajeswari Kamisetti ${ }^{1 *}$, Moses Mekala ${ }^{2}$, Sudhakar Muvvala ${ }^{2}$, \\ Durga Bhavani Penmatsa ${ }^{1}$
}

1Vishnu Institute of Pharmaceutical Education and Research, (Affiliated to Jawaharlal Nehru Tech. University, Hyderabad), Narsapur, Medak, Hyderabad 502313.

2Malla Reddy College of Pharmacy (Affliated to Osmania University), Dhulapally, Maisammaguda, Secunderabad. 500014.

Submitted: $28-08-2014$

Revised: 20-09-2014

Accepted: 05-12-2014

*Corresponding author Raja Rajeswari Kamisetti

Email:

rajeswarimpharm@gmail.com

\begin{abstract}
As precision of dosing and patient compliance become an important prerequisite for a long-term treatment of Tourette's syndrome there is a need to develop formulation for this drug, which overcomes problems such as difficulty in swallowing, inconvenience in administration while travelling and patient's acceptability. The present work was undertaken with a view to develop a fast dissolving tablets of Pimozide using Kyron T-314 as super-disintegrant along with Avicel PH 102 as diluent by response surface method using direct compression. Drugexcipient compatibility studies were confirmed by FTIR Spectroscopy. The tablets were evaluated for hardness, friability, weight variation, wetting time, disintegration time and uniformity of content and in vitro dissolution. Based on evaluating parameters, formulation prepared by using $4.5 \%$ Kyron T-314 with $11.5 \%$ Avicel $\mathrm{PH}-102$ was selected as optimized formulation and Formulation (F3) had disintegration time of $7.63 \pm 0.25 \mathrm{~s}$ and percentage cumulative drug release of 81.60 after $10 \mathrm{~min}$. The formulations were further studied and confirmed for their stability. Hence it was concluded that direct compression using Kyron T-314 superdisintegrant and Avicel PH 102 was simple and economic technique which can be used for formulation of fast dissolving tablets of Pimozide.
\end{abstract}

Key word: Pimozide, Tourette's syndrome, fast dissolving tablets, Kyron T 314, direct compression

\section{INTRODUCTION}

Across a wide variety of disease states, recent advances in drug delivery technologies have led to the development of innovative delivery systems designed to improve therapeutic outcome. Emerging delivery platforms for improved convenience and adherence with psychiatric medications is achieved with fast dissolving tablets (FDTs) which are ahead among the novel oral drug-delivery systems especially in pediatric and geriatric population with Dysphagia (Kane et al., 2003).

Tourette's syndrome is a chronic neuro developmental disorder characterized by repetitive, stereotyped, involuntary movements and vocalizations called tics which have a significant impact on patients' daily functioning across many domains. Tics tend to be most severe in child and adolescent sufferers, so their presence has the potential to impact a period of life that is both critical for learning and is often associated with the experience of greater social tension and self-consciousness than adulthood. Furthermore, control over tics that lead to physical impairment or self-injurious behavior is vital importance in maintaining of health and quality of life (James et al., 2002).

Pimozide is an orally active antipsychotic agent of the diphenyl-butylpiperidine series indicated for the suppression of motor and phonic tics in patients with Tourette's syndrome who have failed to respond satisfactorily to the standard treatment (Clare et al., 2011). Pimozide also has less potential for inducing sedation and hypotension as it has more strong and specific dopamine receptor blocking activity upon the post synaptic dopamine receptor than other neuroleptic agents and therefore a suitable alternative to haloperidol (Seemen 2002). Pimozide has an elimination half-life of $55 \mathrm{~h}$ and undergoes hepatic metabolism and has about 40-50\% bioavailability (Fog, 1980; Logan et al., 1982). 
Table I. Level of formulation variables

\begin{tabular}{lllllll}
\hline & Name & Units & Low & High & -alpha & +alpha \\
\hline A [Numeric] & Kyron T-314 & $\mathrm{mg}$ & 9 & 15 & 7.75736 & 16.2426 \\
B [Numeric] & Avicel PH 102 & $\mathrm{mg}$ & 12 & 23 & 9.72183 & 25.2782 \\
\hline
\end{tabular}

Table II. Formulation of FDTs of pimozide

\begin{tabular}{llllllllll}
\hline Ingredients & F1 & F2 & F3 & F4 & F5 & F6 & F7 & F8 & F9 \\
\hline Pimozide & 1 & 1 & 1 & 1 & 1 & 1 & 1 & 1 & 1 \\
Kyron T-314 & 9 & 9 & 9 & 12 & 12 & 12 & 15 & 15 & 15 \\
Avicel PH 102 & 12 & 17 & 23 & 12 & 17 & 23 & 12 & 17 & 23 \\
Mannitol & 171 & 166 & 160 & 168 & 163 & 157 & 165 & 160 & 154 \\
Acryflow-L & 3 & 3 & 3 & 3 & 3 & 3 & 3 & 3 & 3 \\
Talc & 4 & 4 & 4 & 4 & 4 & 4 & 4 & 4 & 4 \\
\hline Total weight & 200 & 200 & 200 & 200 & 200 & 200 & 200 & 200 & 200 \\
\hline
\end{tabular}

1 and 3 shows CSF3syn.Ec3 as restriction product D. Colony PCR of BL21(DE3)_pET32a(+)_CSF3syn.Ec3 with $\mathrm{R}$ - and $\mathrm{F}$ - insert gene primers. $\mathrm{M}=1 \mathrm{~kb}$ DNA Marker; $\mathrm{NC}=$ negative control; $\mathrm{PC}=$ positive control or recombinant plasmid pET32a(+)_CSF3syn.Ec3

The solubility of pimozide in water is less than $0.01 \mathrm{mg} / \mathrm{mL}$; slightly soluble in most organic solvents.

Fast dissolving tablets combines the advantages of both liquid and conventional tablet formulations, while also offering advantages over both traditional dosage forms like enhanced bioavailability, avoidance of first pass hepatic metabolism and convenience Various techniques used in formulating FDTs include Molding Moulding (Habib et al., 2000), Spray drying (Biradar et al., 2006) Mass extrusion, Sublimation, Direct compression, Freeze drying /lyophilization, Cotton candy process (Reddy et al., 2002., Khalid et al., 2011), Phase transition techniques (Sadhana et al., 2013) etc. Direct compression technique (Dobetti et al., 2001) utilizes conventional equipment, commonly available excipients and a limited number of processing steps makes this the easiest process to manufacture FDTs. High doses can be accommodated and the final weight of the tablet can easily exceed that of other production methods. Kyron T-314 is a novel polacrillin potassium superdisintegrants derived from cross linked polymer of Polycarboxylic acids as per USP/NF \& has the $\mathrm{K}^{+}$ionic form. It is a very high purity polymer used in pharmaceutical formulations as a super-fast disintegrants as well as dissolution improver in solid dosage forms like tablets, capsules, pellets etc
(Chaudary et al., 2005). Acry flow-L is chemically poly 12-hydroxy stearate widely used in oral dosage formulations as an excellent tablet lubricant. It is high molecular weight polymer and does not get absorbed by body tissue and hence safe for human consumption and hence has no physiological action at recommended dosage (Bi et al., 1995).

An attempt has been made to develop fast dissolving tablets of pimozide with a novel superdisintegrant Kyron T-314 using response surface method by direct compression method. Based on the preliminary studies, the ranges for the formulations were selected, the response (dependent) variables being Disintegration time (DT).

\section{MATERIAL AND METHODS}

Pimozide was gifted by Vasudha Pharma Chem Pvt Ltd, Hyderabad. Kyron T314 and Acry flow L were obtained as gift samples from Corel Pharma Chem., (Ahmedabad, India). All other chemicals and reagents used were of analytical grade and used as supplied by the manufacturer.

\section{Experimental design \\ Solubility study of pimozide}

Solubility studies of pimozide were carried out in $0.01 \mathrm{~N} \mathrm{HCl}$, acetate buffer $\mathrm{pH}$ 4.5, phosphate buffer $\mathrm{pH}$ 6.8, phosphate buffer $\mathrm{pH} 7.2$ and distilled water. 
A sample of $20 \mathrm{mg}$ of pure pimozide was taken in $15 \mathrm{~mL}$ screw cap test tubes containing $10 \mathrm{~mL}$ of media. The solutions were shaken and kept aside for $24 \mathrm{~h}$ with continuous stirring. After $24 \mathrm{~h}$, the sample solutions were filtered through Whatmann filter paper which a filtrate of $1 \mathrm{~mL}$ was diluted to a suitable concentration with respective buffer media. The absorbance of the prepared dilutions were measured at $278 \mathrm{~nm}$ using UV-Visible spectrophotometer. The results were tabulated as shown in table III

\section{Experimental design}

The present study involved Response Surface Method with 2 factors as shown in table I. Experimental trials were performed as shown in table II.

\section{Formulation of fast dissolving tablets}

FDTs were prepared by direct compression method. Nine different formulations were prepared using Kyron T 314 as a superdisintegrants and Avicel $\mathrm{PH} 102$ as diluent. All the ingredients (Pimozide, mannitol, Avicel pH 102), except Acry flow L and Talc were passed through 60 mesh size separately and mixed. Then Acry flow L and Talc as Lubricant and Glidant respectively were added and compressed into tablet using $8 \mathrm{~mm}$ punch on rotary tablet compression machine. Table II show the formulation of FDTs of Pimozide.

\section{Evaluation of FDTs}

The FDTs were studied further for chemical interaction using Infra-red Spectroscopy. The results were shown in figures 1 and 2 and table IV.

\section{Evaluation of pre-compression parameters}

The prepared powder tablet blend was evaluated for their pre-compression parameters including bulk density $(D b)$, tapped density $(\varrho t)$, Carr's compressibility index (I), Hausner ratio $(\mathrm{H})$ and Angle of Repose $(\theta)$. The results were shown in table $\mathrm{V}$.

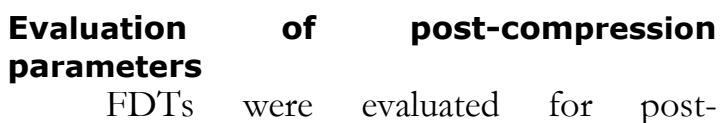
compression parameters like weight variation, Hardness, Friability, and thickness. The results were tabulated as shown in table VI.

\section{Wetting time and water absorption ratio}

Wetting time and water absorption ratio were calculated by taking a piece of tissue paper of internal diameter $6.5 \mathrm{~cm}$ was folded twice and placed in a small petri dish containing $6 \mathrm{~mL}$ of water. A tablet was put on the middle of the paper, and the time for complete wetting was measured. The wetted tablet was reweighed to calculate the water absorption ratio was calculated by the following formula: $\mathrm{R}=100 \times\left(\mathrm{W}_{\mathrm{a}}-\mathrm{W}_{\mathrm{b}}\right) / \mathrm{W}_{\mathrm{a}}$

Where $\mathrm{W}_{\mathrm{a}}$ is weight of tablet after water absorption and $\mathrm{W}_{\mathrm{b}}$ is weight of tablet before water absorption. Three trials for each batch were performed and standard deviation was also determined.

\section{In vitro dispersion time}

The study was conducted by placing a tablet in a beaker containing $10 \mathrm{~mL}$ of $\mathrm{pH} 6.8$ buffer at $37 \pm 0.5^{\circ}$ and the time required for complete dispersion was determined.

\section{Drug content uniformity}

The content uniformity was determined by Placing a tablet in a $50 \mathrm{~mL}$ round-bottomed flask (RBF), add $5 \mathrm{~mL}$ of $0.1 \mathrm{~N} \mathrm{HCl}$, and shaken by mechanical stirrer for $30 \mathrm{~min}$ to which $20 \mathrm{~mL}$ of methanol was added and shaken for 20 more minutes. Dilutions with methanol were made to obtain a solution having a concentration of about $40 \mu \mathrm{g}$ of Pimozide per $\mathrm{mL}$, mixed centrifuged at $1000 \mathrm{rpm}$. Concomitantly, the absorbance of the solution of Pimozide was observed at $277 \mathrm{~nm}$, using a double beam UVVisible spectrophotometer (TDT-08L, Electrolab, India), against methanol as a blank. Further the drug content was measured using the formula as below: (TC/D) $\left(\mathrm{A}_{\mathrm{U}} / \mathrm{A}_{\mathrm{S}}\right)$

Where ' $\mathrm{T}$ ' is the labeled quantity of Pimozide (in $\mathrm{mg}$ ) in the Tablet, ' $\mathrm{C}$ ' is the concentration, in $\mu \mathrm{g}$ per $\mathrm{mL}$, of Pimozide in the Standard solution, 'D' is the concentration, in $\mu \mathrm{g} / \mathrm{mL}$, of Pimozide in the solution from the tablet.

' $A_{U}^{u}$ ' and 'As' are the absorbance of the solution from the tablet and the Standard solutions respectively. 
Raja Rajeswari Kamisetti

Table III. Solubility behavior of pimozide

\begin{tabular}{lll}
\hline Buffers & Absorbance & Concentration $(\mathbf{m g} / \mathbf{m L})$ \\
\hline $0.01 \mathrm{~N} \mathrm{HCl}$ & 0.255 & 0.023091 \\
$4.5 \mathrm{pH}$ & 0.241 & 0.021818 \\
$6.8 \mathrm{pH}$ & 0.196 & 0.017727 \\
$7.2 \mathrm{pH}$ & 0.130 & 0.011727 \\
$\mathrm{H}_{2} \mathrm{O}$ & 0.079 & 0.007118 \\
\hline
\end{tabular}

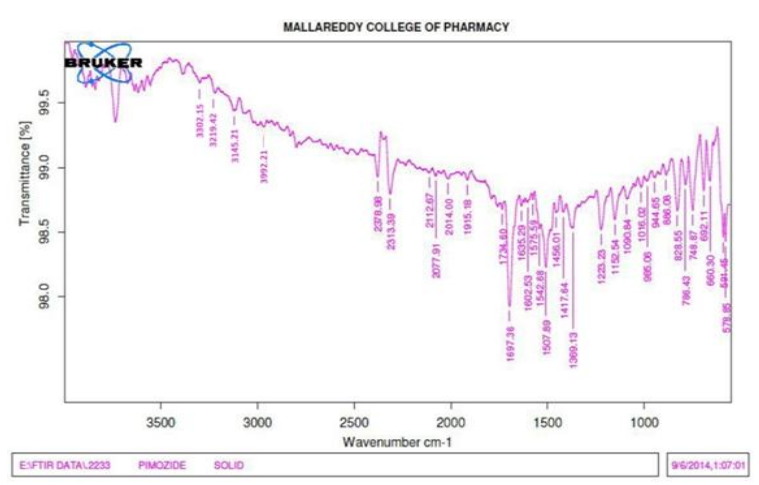

Figure 1. IR Spectra of pimozide.

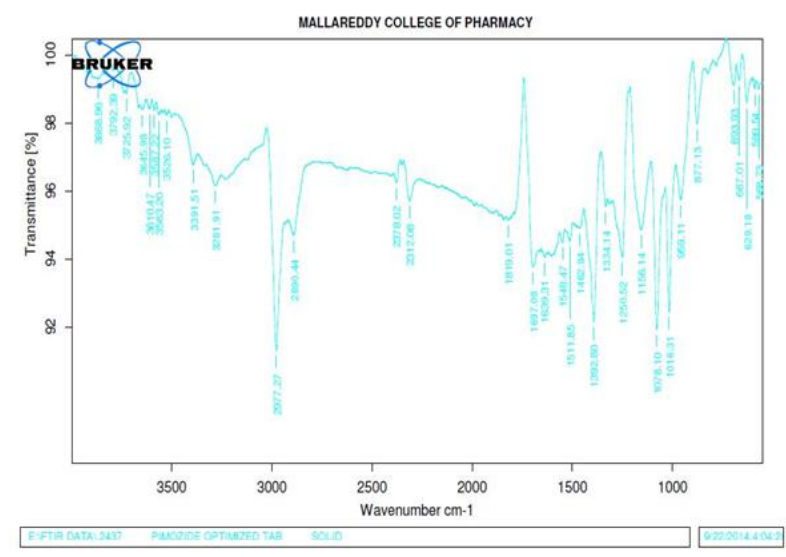

Figure 2. IR Spectra of pimozide and physical mixture with excipients.

\section{In vitro disintegration time}

In vitro disintegration test was carried out in USP tablet disintegration apparatus by placing one tablet in each of the 6 tubes of the basket containing $\mathrm{pH} 6.8$ phosphate buffer as medium maintained at $37 \pm 2{ }^{\circ} \mathrm{C}$. The time required in seconds for the complete disintegration of the tablet with no visible mass remaining in the apparatus was measured and recorded. The results of wetting time, in vitro dispersion time, drug content uniformity and in vitro disintegration time were shown in table VII.

\section{In vitro dissolution studies}

In vitro dissolution studies were carried out in USP Type II paddle apparatus (Lab India, India) maintained at $37 \pm 0.5^{\circ} \mathrm{C}$ using $900 \mathrm{~mL}$ of phosphate buffer $\mathrm{pH} 6.8$ as the dissolution medium at 50rpm. Aliquots of the samples were collected at specified time intervals and were replaced with the fresh medium after each withdrawal. The samples were observed for their respective absorbances at $277 \mathrm{~nm}$ by UV spectrometry and their cumulative percentage drug release was calculated (Figure 3 and 4). 
Table IV. Drug-excipient interactive studies.

\begin{tabular}{|c|c|c|c|c|}
\hline \multirow[b]{2}{*}{ NO } & \multicolumn{2}{|c|}{ Wave number in formulation $\left(\mathrm{cm}^{-1}\right)$} & \multirow{2}{*}{$\begin{array}{l}\text { Characteristic } \\
\text { wave number } \\
\text { range }\left(\mathrm{cm}^{-1}\right)\end{array}$} & \multirow[b]{2}{*}{$\begin{array}{l}\text { Bond nature and bond } \\
\text { attributed }\end{array}$} \\
\hline & Pure drug & $\begin{array}{l}\text { Optimized } \\
\text { formulation }\end{array}$ & & \\
\hline 1 & 3219.42 & 3281.91 & $3400-3250$ & N-H stretching \\
\hline 2 & 1697.36 & 1697.08 & $1640-1690$ & $\mathrm{C}=\mathrm{O}$ stretching(amines) \\
\hline 3 & 1635.29 & 1639.31 & $1550-1640$ & N-H bending (amines) \\
\hline 4 & 1507.89 & 1511.85 & $1400-1600$ & $\mathrm{C}=\mathrm{H}$ stretching in Aromatics. \\
\hline 5 & 1223.23 & 1250.52 & $1000-1400$ & C-F strong stretching Mono \\
\hline 6 & 692.11 & 693.93 & $690-710$ & $\begin{array}{l}\text { substituted cycloalkane } \\
\text { C-H deformation }\end{array}$ \\
\hline
\end{tabular}

TableV. Evaluation of pre-compression parameters of fast dissolving tablets

\begin{tabular}{cccccc}
\hline $\begin{array}{c}\text { Formulation } \\
\text { code }\end{array}$ & $\begin{array}{c}\text { Bulk density } \\
(\mathbf{g m} / \mathbf{c c})\end{array}$ & $\begin{array}{c}\text { Tapped density } \\
\mathbf{( g m / c c )}\end{array}$ & $\begin{array}{c}\text { Angle of repose } \\
\text { (degrees) }\end{array}$ & $\begin{array}{c}\text { Carr's index } \\
\mathbf{( \% )}\end{array}$ & $\begin{array}{c}\text { Hausner } \\
\text { ratio }\end{array}$ \\
\hline F1 & $0.48 \pm 0.12$ & $0.58 \pm 0.10$ & $27.47 \pm 0.11$ & $17.241 \pm 0.11$ & $1.208 \pm 0.11$ \\
F2 & $0.47 \pm 0.10$ & $0.57 \pm 0.10$ & $24.70 \pm 0.11$ & $17.544 \pm 0.12$ & $1.213 \pm 0.12$ \\
F3 & $0.46 \pm 0.13$ & $0.57 \pm 0.10$ & $26.59 \pm 0.10$ & $19.298 \pm 0.10$ & $1.239 \pm 0.10$ \\
F4 & $0.49 \pm 0.11$ & $0.59 \pm 0.11$ & $26.54 \pm 0.13$ & $16.949 \pm 0.14$ & $1.204 \pm 0.13$ \\
F5 & $0.47 \pm 0.11$ & $0.6 \pm 0.10$ & $25.64 \pm 0.11$ & $21.667 \pm 0.10$ & $1.277 \pm 0.10$ \\
F6 & $0.47 \pm 0.11$ & $0.59 \pm 0.12$ & $25.41 \pm 0.13$ & $20.339 \pm 0.1$ & $1.255 \pm 0.22$ \\
F7 & $0.45 \pm 0.13$ & $0.57 \pm 0.14$ & $24.70 \pm 0.10$ & $21.053 \pm 0.11$ & $1.267 \pm 0.11$ \\
F8 & $0.47 \pm 0.11$ & $0.59 \pm 0.13$ & $25.61 \pm 0.10$ & $20.339 \pm 0.12$ & $1.255 \pm 0.11$ \\
F9 & $0.46 \pm 0.11$ & $0.56 \pm 0.11$ & $23.79 \pm 0.12$ & $17.857 \pm 0.11$ & $1.217 \pm 0.13$ \\
\hline
\end{tabular}

Table VI. Evaluation of post-compression parameters of fast dissolving tablets

\begin{tabular}{ccccc}
\hline $\begin{array}{c}\text { Formulation } \\
\text { code }\end{array}$ & $\begin{array}{c}\text { Hardness } \\
\mathbf{S D}\left(\mathbf{k g} / \mathbf{c m}^{2}\right)\end{array}$ & Friability $\mathbf{( \% )}$ & $\begin{array}{c}\text { Thickness } \\
\mathbf{( m m})\end{array}$ & $\begin{array}{c}\text { Weight variation } \\
\mathbf{+} \mathbf{S D}(\mathbf{m g})\end{array}$ \\
\hline F1 & $3.05 \pm 0.53$ & $0.55 \pm 0.15$ & $2.97 \pm 0.058$ & $197.43 \pm 2.23$ \\
F2 & $3.12 \pm 0.121$ & $0.56 \pm 0.11$ & $2.92 \pm 0.053$ & $199.14 \pm 2.91$ \\
F3 & $3.11 \pm 0.102$ & $0.4 \pm 0.11$ & $2.93 \pm 0.061$ & $197.57 \pm 2.3$ \\
F4 & $3.09 \pm 0.091$ & $0.51 \pm 0.12$ & $2.98 \pm 0.075$ & $197.14 \pm 2.19$ \\
F5 & $3.15 \pm 0.139$ & $0.85 \pm 0.11$ & $2.96 \pm 0.036$ & $196.71 \pm 1.98$ \\
F6 & $3.14 \pm 0.131$ & $0.6 \pm 0.11$ & $2.87 \pm 0.08$ & $197.43 \pm 2.15$ \\
F7 & $3.13 \pm 1.125$ & $0.66 \pm 0.15$ & $2.92 \pm 0.045$ & $196.86 \pm 2.04$ \\
F8 & $3.12 \pm 0.122$ & $0.72 \pm 0.11$ & $2.93 \pm 0.070$ & $198.57 \pm 2.07$ \\
F9 & $3.16 \pm 0.077$ & $0.65 \pm 0.11$ & $2.90 \pm 0.042$ & $198.43 \pm 2.76$ \\
\hline
\end{tabular}

\section{Stability studies}

Short-term stability studies on the promising formulations (F3) were carried out by storing the tablets in an amber coloured rubber stoppered vial at $40^{\circ} / 75 \% \mathrm{RH}$ for 3 months. At an interval of 1 month, the tablets were visually examined for any physical changes, changes in drug content and in vitro dispersion time.

\section{RESULTS AND DISCUSSION}

Solubility studies showed distinct solubility of Pimozide very poor solubility in distilled water and moderate solubility in buffers of $\mathrm{pH} 7.2$ and 6.8. The drug was found to have better solubility in $0.01 \mathrm{~N} \mathrm{H} \mathrm{Cl}$ and buffer of $\mathrm{pH} 4.5$ (Table III). The results indicate that there were no possible chemical interactions between the drug and the 
Raja Rajeswari Kamisetti

Table VII. Evaluation of post-compression parameters of fast dissolving tablets

\begin{tabular}{cccl}
\hline Formulation Code & $\begin{array}{c}\text { Wetting time } \\
+ \text { SD (Sec) }\end{array}$ & $\begin{array}{c}\text { Disintegration } \\
\text { time + SD (Sec) }\end{array}$ & $\begin{array}{c}\text { \% Drug } \\
\text { content }\end{array}$ \\
\hline F1 & $15.5 \pm 0.66$ & $8.30 \pm 0.19$ & $98.43 \pm 0.98$ \\
F2 & $15.4 \pm 0.44$ & $9.4 \pm 0.26$ & $97.37 \pm 1.4$ \\
F3 & $14.5 \pm 0.35$ & $7.63 \pm 0.25$ & $99.10 \pm 1.97$ \\
F4 & $16.8 \pm 0.36$ & $8.6 \pm 0.30$ & $98.90 \pm 1.9$ \\
F5 & $17.3 \pm 0.46$ & $10.48 \pm 0.3$ & $98.33 \pm 2.61$ \\
F6 & $16.6 \pm 0.53$ & $9.36 \pm 0.25$ & $98.33 \pm 2.61$ \\
F7 & $17.3 \pm 0.60$ & $9.7 \pm 0.26$ & $96.10 \pm 1.37$ \\
F8 & $20.9 \pm 0.56$ & $10.8 \pm 0.53$ & $97.57 \pm 1.22$ \\
F9 & $21.2 \pm 0.36$ & $10.9 \pm 0.20$ & $97.23 \pm 1.5$ \\
\hline
\end{tabular}

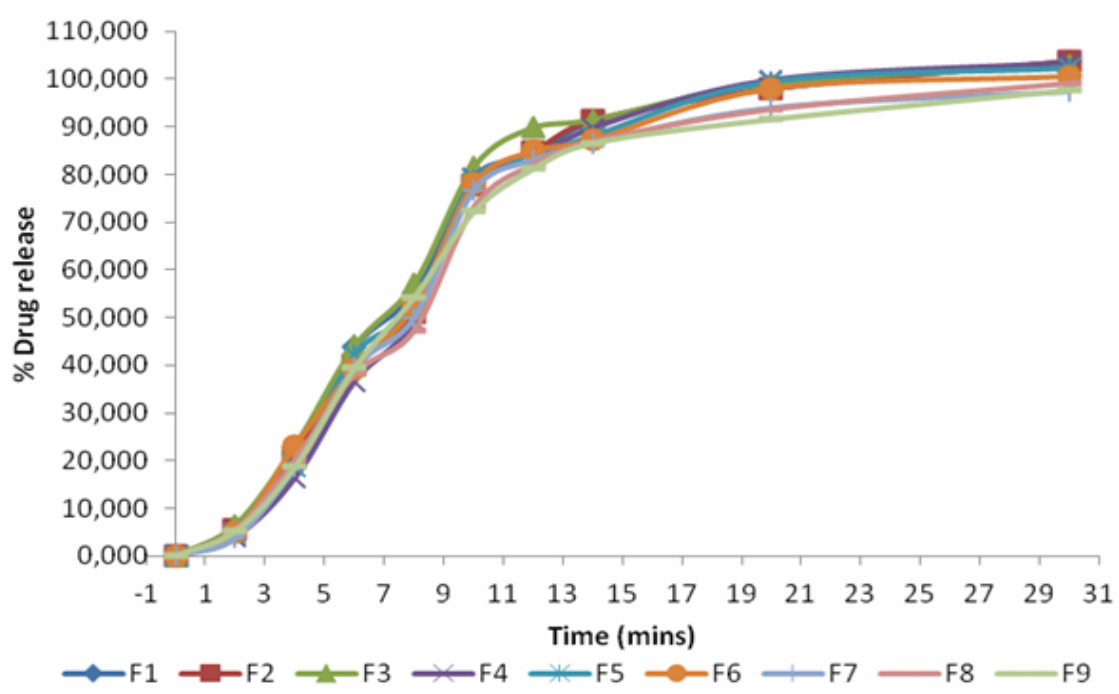

Figure 3. Invitro dissolution profile of FDTs of Pimozide

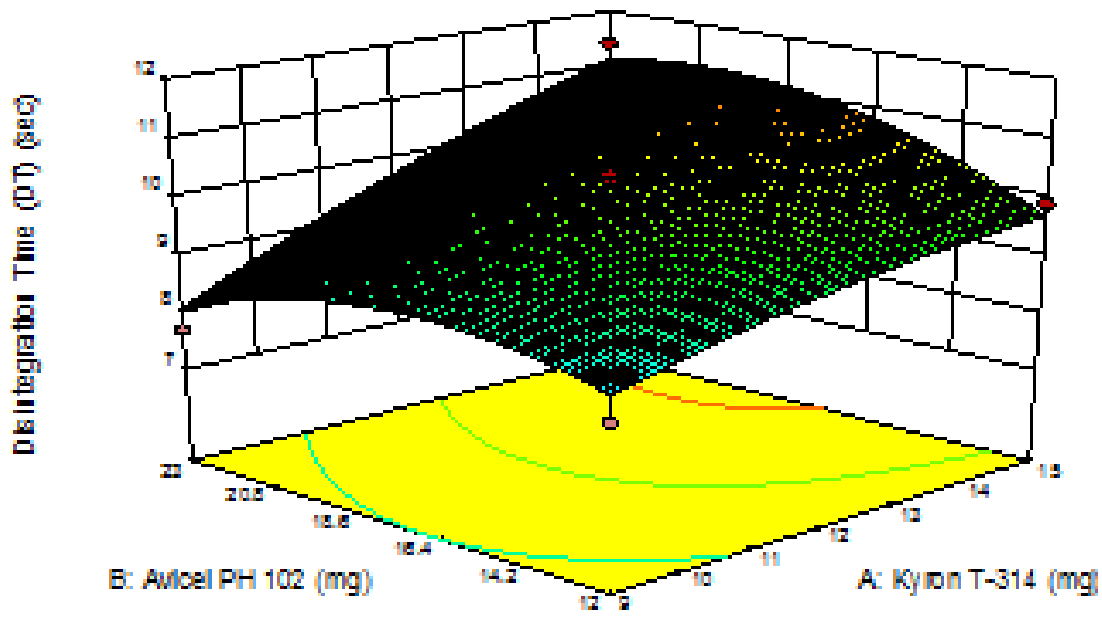

Figure 4. Contour plot of FDTs of pimozide 
excipients (Figure 1, 2 and Table IV). The precompression parameters were found to within the specified limits and show on table V. The results of evaluation post-compression parameters were found to be within the limits (Table VI and VII)

\section{In vitro dissolution time profile Optimization}

The Model F-value of 16.56 implies the model is significant. There is only a $0.09 \%$ chance that an F-value this large could occur due to noise. Values of "Prob> F" less than 0.0500 indicate model terms are significant.

The optimization model was found to be significant with $F$ value 33.32 and $p$-value of 0.0027. It was found that disintegration time increased with an increase in the concentration of Kyron $\mathrm{T}$ 314. Formulation $\mathrm{F} 3$ got disintegrated in $7.63 \mathrm{~s}$. Hence it was concluded that Formulation F3 was optimized.

\section{Stability studies}

Accelerated stability studies on the promising formulations (F3) were found to have physical stability without any morphological changes and the drug content was found to be within the limits.

\section{CONCLUSION}

Hence it has been concluded that Design of Experiments following Response Surface Methodology can be effectively used in the design, formulation and evaluation of FDTs of drugs. By adopting a systematic formulation approach (DOE-RSM), an optimum point can be reached in the shortest time with minimal efforts. Pimozide fast dissolving tablets can be successfully prepared using Kyron T-314 as superdisintegrant which effectively reduces the disintegration time and thus enhance patient compliance.

\section{ACKNOWLEDGEMENTS}

The authors express their sincerely thanks to Malla reddy college of Pharmacy, Secunderabad.

\section{REFERENCES}

Biradar SS., Bhagavati ST., Kuppasad IJ. 2006. Fast dissolving drug delivery systems: A brief overview. Int J Pharmacol., v.24(2), p.1-7,

Bi YX., Sunada H., Yonezawa Y., Danjo K. 1999. Evaluation of rapidly disintegrating tablets by direct compression method. Drug Develop Ind Pharm., v.25, p. 571-581,

Chaudhari PD., Chaudhari SP., Kohle SR., Dave KV, More DM. 2005. Formulation and evaluation of fast dissolving tablets of famotidine. Ind. Drugs.,v.42, p.641-649

Clare ME., Hugh E., Rickard. 2011. Treatment Strategies for tics in Tourette Syndrome. Ther Adv. Neurol Disord., v.4(1), 25-45

Dobetti L. 2001. Fast-melting tablets: Developments and technologies. Pharm Technol N Am., V. 12(9), p.44-50.

Logan FA., Herrington RN., Mackie MM., Rubin PC., 1982 Pimozide: adverse reaction and prolonged half-life. Brit $J$ Psyc.,v. 140, p.433-4

Fog R., Pakkenberg H., 1980. Theoritical and Clinical aspects of the Tourettic Syndrome (chronic multiple tic).J.NeuralTransm., v.16, p.211-5,

Habib W., Khankari R., Hontz J., 2000. FastDissolve Drug Delivery System. Crit Rev Ther Drug Carrier Syst., v.17, p.61-72,

James FL., 2002. Toutte's Syndrome. The Lancet., V. 360, P. 1577-158

Kane Jm., Eerdekens M., Lindenmayer JP., 2003. Long-acting injectable risperidone: Efficacy and safety of the first long-acting atypical antipsychotic. Am. J Psychiatry., v.160: p.1125-32,

Sadhana RS., Minakshi VK., Somshekhar S., Nityanand Z., 2013. Formulation and Evaluation of Atenolol Orodispersible tablets by Phase Transition technology., V. 5: 13: P.604-609,

Seeman P. 2002. Atypical antipsychotics: mechanism of action. Can J Psychiatry., v. 47(1): p.27-38 